\author{
Ch. Kyriakopoulos, E. Liveri \& D. Phitos
}

\title{
Campanula kamariana (section Quinqueloculares), a new species from S Peloponnisos, Greece
}

\begin{abstract}
Kyriakopoulos, Ch., Liveri, E. \& Phitos, D.: Campanula kamariana (section Quinqueloculares), a new species from S Peloponnisos, Greece. - Fl. Medit. 27: 131-135. 2017. - ISSN: 1120-4052 printed, 2240-4538 online.

In the framework of the first author's Ph.D. dissertation on the study of the flora of Mt. Taigetos (south Peloponnisos) and surrounding areas, as well as the molecular phylogenetic study of Campanula (section Quinqueloculares) by the second author, a new species, C. kamariana, was discovered in the surrounding area of Mt. Taigetos and hereby described. The chromosome number is provided, together with a discussion on the main morphological differences with the seemingly closely related $C$. topaliana s. 1 , as well as with other taxa in section Quinqueloculares. The appropriate conservation status for this species is also recommended.
\end{abstract}

Key words: Campanulaceae, Greek flora, endemism, conservation.

\section{Introduction}

In a recent publication on species of Campanula in section Quinqueloculares (Phitos 2016), as well as in a previous publication by Phitos (1965), it was particularly emphasized the need for a broader study focusing on the strong morphological polymorphism exhibited by this group in order to generate a more informed classification. This ongoing effort is under the guidance of Prof. D. Phitos and Prof. G. Kamari, and the second author, Ms. E. Liveri, is undertaking the molecular study of section Quinqueloculares in collaboration with Assoc. Prof. N. Cellinese (Florida Museum of Natural History, University of Florida, USA). This research, combined with the study of the rare and endemic species on Mt. Taigetos and surrounding areas (Kyriakopoulos, in prep.), have resulted in the discovery of a new species, Campanula kamariana, in southern Peloponnisos.

\section{Material and methods}

Living plants of Campanula kamariana were examined in the field. A few specimens are kept under cultivation at the University of Patras. The description of the new species was based on both dry specimens and living material. For the morphological analysis we 
consulted dry herbarium material kept in Herb.-Phitos \& Kamari (UPA). For the karyological investigations we used the classical squash technique by Östergren \& Heneen (1962) and Kamari (1976), with some small modifications (Phitos \& Kamari 1988).

\section{Results}

Campanula kamariana Kyriak., Liveri \& Phitos sp. nov. (Figs. 1 \& 2).

Diagnosis: Campanula kamariana belongs to section Quinqueloculares. It differs from all other Campanula taxa in this section, especially from the seemingly closely related $C$. topaliana Beauverd (which is mainly distributed in central and western Peloponnisos), by having strongly lacerate, sparsely pubescent to glabrescent rosette leaves with long, sparsely lobed petioles. Additionally, it differs by having small, triangular, rarely ovate, appendages, not covering the ovary.

Typus: S Peloponnisos (Greece), Nomos Lakonias: Areopolis area, west entrance of Limeni, $36^{\circ} 40^{\prime} 45.71$ ” N, 22 $2^{\circ} 22^{\prime} 31.89^{\prime \prime}$ E, ca. 20-30 m a.s.1., limestone rocks, N-NW orientation, 30 Apr. 2017, leg. Ch. Kyriakopoulos 2321 (Holo: Herb.-Phitos \& Kamari!). Isotypi: UPA!, ACA!, and PAL-Gr!

Description: Biennial or monocarpic perennial, with stout, woody tap-root. Basal leaves in a rosette, $\pm 17 \mathrm{~cm}$ long, long-petiolate with sparsely lobed petioles; blade of rosette leaves $\pm 7 \times 4.5 \mathrm{~cm}$, longitudinal lanceolate and strongly lacerate, sparsely pubescent to glabrescent. Flowering stems several, up to $30 \mathrm{~cm}$ long, procumbent, appressed to the rock, simple or sparingly branched. Lower cauline leaves long petiolate, oblanceolate, laciniate; the uppermost leaves short petiolate, oblanceolate, serrate. Flowers short pedicellate. Calyx lanuginous, with teeth long triangular, acuminate, \pm half as long as corolla tube; calyx appendages small, triangular rarely ovate, not covering the ovary. Corolla relatively small, 9-12 mm long, tubular, sparsely puberulent, pale violet-blue; lobes obovate. Capsule (4-)5-locular, stigmas (4-)5.

Karyology: Plants from the locus classicus of Campanula kamariana, were analyzed karyologically. Results showed a chromosome number $2 n=34$ and a symmetrical karyotype with mostly metacentric $(\mathrm{m})$ chromosomes. The chromosome number and karyotype morphology of $C$. kamariana is congruent with most Campanula species in section Quinqueloculares, especially with the C. topaliana species complex.

Phenology: Flowering from April to the middle of May. Fruiting from May to the middle of June.

Specimens seen: Greece: S Peloponnisos, Nomos Lakonias: Areopolis area, west entrance of Limeni, $36^{\circ} 40^{\prime} 45.71^{\prime \prime} \mathrm{N}, 22^{\circ} 22^{\prime} 31.89^{\prime}$ E, ca. 20-30 m a.s.l., limestone rocks, NNW orientation, 30 Apr. 2017, leg. Ch. Kyriakopoulos 2321 [Herb.-Phitos \& Kamari (UPA)]; ibidem: ca. 50-80 m a.s.1., 10 June 2017, leg. Ch. Kyriakopoulos 2332 [Herb.- 


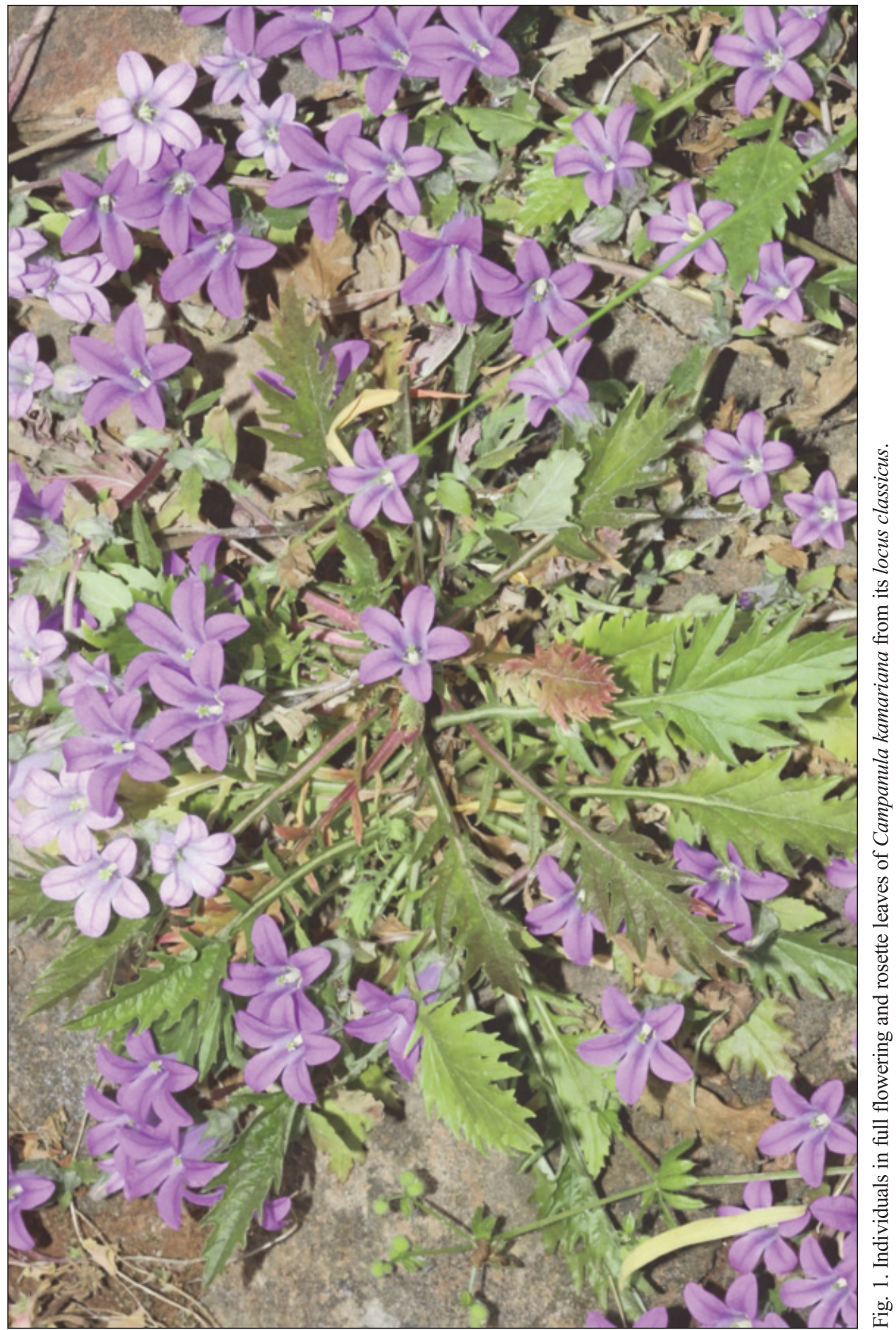




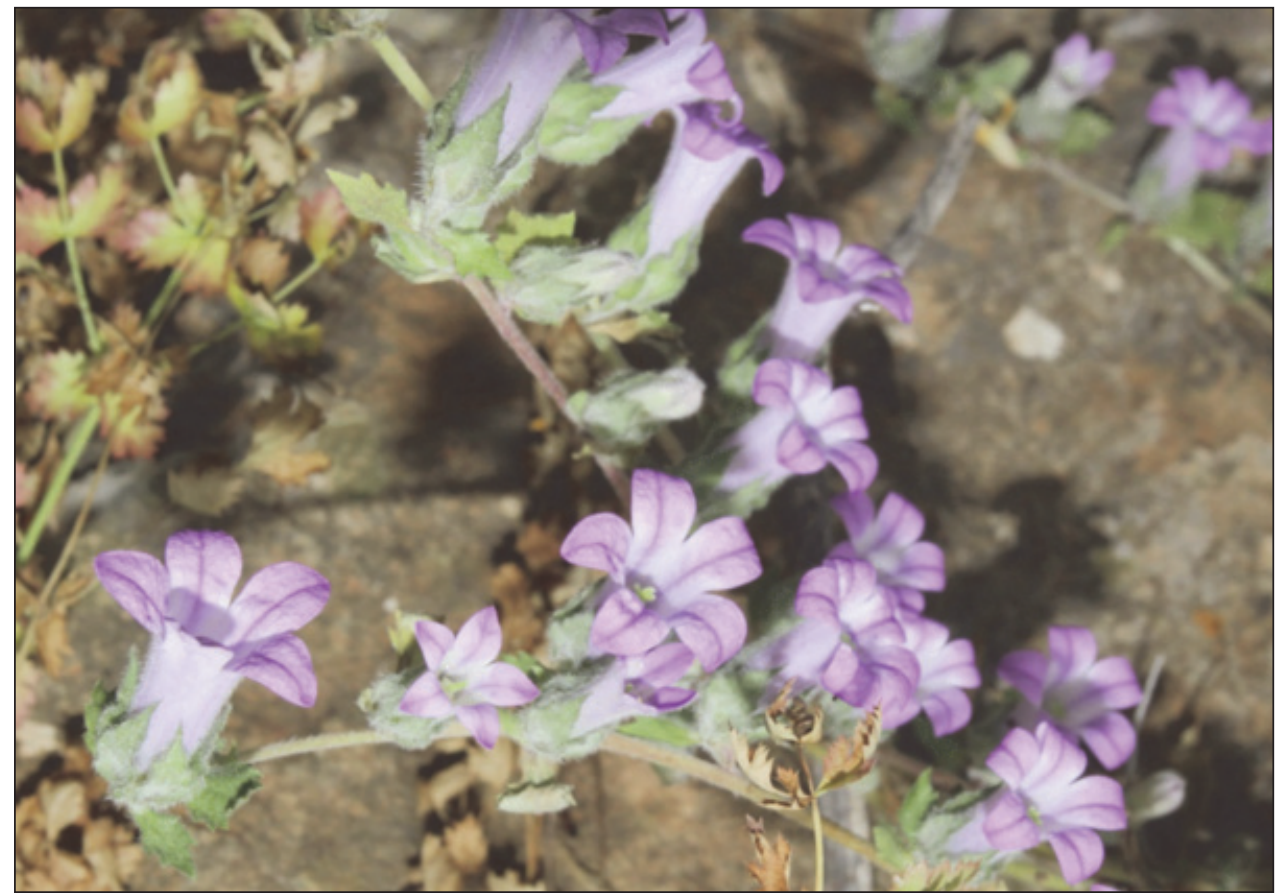

Fig. 2. Flowering stems of Campanula kamariana from its locus classicus.

Phitos \& Kamari (UPA); ibidem: 17 June 2017, leg. E. Liveri \& V. Ketsilis-Rinis 236 [Herb.-Phitos \& Kamari (UPA)].

Distribution and habitat: Campanula kamariana is a chasmophytic species growing usually on limestone rocks, like most other species in section Quinqueloculares. It was found in the peninsula between the Messinian and Lakonian bay in S Peloponnisos. More precisely, in Limeni, a small village closes to the town Areopolis (Messinian Bay). Other chasmophytic species found growing in association with Campanula kamariana include: Scaligeria moreana Engstrand, Stachys canescens Bory \& Chaub., Onosma graeca Boiss., etc.

Conservation status: Campanula kamariana is apparently a rare endemic species. It is known as of now only from the type locality. However, within the broader area of its distribution range, it is possible that some small isolated subpopulations also exist. The population consists of approximately 150-200 mature individuals. Therefore, this species should be classified as Critically Endangered (CR) according to the IUCN (2016) criteria.

Etymology: The species is named after Georgia Kamari, Professor Emeritus of Plant Systematic and Phytogeography at the University of Patras, graduate supervisor of the first two authors. 


\section{Acknowledgements}

We would like to thank V. Ketsilis-Rinis for his friendly availability in the field. Additionally, we would like to thank the anonymous reviewer for the linguistic corrections.

\section{References}

IUCN Standards and Petitions Subcommittee 2016: Guidelines for Using the IUCN Red List Categories and Criteria. Version 12. - Prepared by the Standards and Petitions Subcommittee. Available at http://www.iucnredlist.org/documents/RedListGuidelines.pdf [Last accessed: Feb 2017].

Kamari, G. 1976: Cytotaxonomic study of the Crepis neglecta L. complex in Greece. - Ph.D. thesis, University of Patras, Greece (in Greek with English summary).

Östergren, G. \& Heneen, W. K. 1962: A squash technique for chromosome morphological studies. Hereditas 48: 332-341.

Phitos, D. 1965: Die quinquelokulären Campanula-Arten. - Österr. Bot. Z. 112: 449-498.

- 2016: The section Quinqueloculares of the genus Campanula (Campanulaceae) and its polymorphism - Taxonomic review of the last decades. - Bot. Chron. 21: 91-102.

— \& Kamari, G. 1988: Contribution to the cytotaxonomy of the genus Campanula (Campanulaceae) in Greece. - Willdenowia 17: 103-105.

Adresses of the authors:

Charalampos Kyriakopoulos, Eleni Liveri \& Dimitrios Phitos,

Botanical Institute, Department of Biology, University of Patras, 26500 Patras, Greece.E-mails: hakyri@yahoo.gr; eleni-liveri@hotmail.com; dphitos@upatras.gr 
